\title{
Renal loss of folate in the newborn infant
}

\author{
M. J. LANDON and E. N. HEY \\ From the University Department of Child Health and M.R.C. Reproduction and Growth Unit, Princess Mary \\ Maternity Hospital, Newcastle upon Tyne
}

Landon, M. J., and Hey, E. N. (1974). Archives of Disease in Childhood, 49, 292. Renal loss of folate in the newborn infant. Renal excretion of folate during the first 5 days of life has been measured in 10 infants of 31 to 40 weeks' gestation and compared with inulin clearance. Average daily folate loss per unit surface area (23 $\mu \mathrm{g} / \mathrm{m}^{2}$ ) was nearly 8 times as high as in adult life and more than enough to account for the observed fall in plasma folate activity. No difference was detected between the pattern of folate excretion in preterm and term infants. Poor tubular reabsorption of filtered folate is thought to be responsible for the loss observed.

A number of studies have established that red cell and plasma folate levels both fall significantly during the neonatal period (Strelling et al., 1966; Vanier and Tyas, 1966; Roberts et al., 1969). The fall is usually interpreted as indicating that dietary intake is inadequate to meet tissue demand and that, in consequence, the body stores present at birth are rapidly exhausted; however Landon and Oxley (1971) suggested that loss in the urine might be responsible for some of the observed fall and the present study was undertaken to investigate this possibility.

\section{Subjects and methods}

Consecutive 12-hour urine collections were available from 10 infants in whom renal function was being studied for another purpose. The initial criteria for selection were an uneventful pregnancy of known duration and a normal delivery. The infants were either of short gestation or small-for-dates so that (with the exception of Case 1) they were all of comparable weight at birth (Table III). They remained clinically well throughout the period of study (except Case 3 who developed mild respiratory distress). Intravenous glucose was given on clinical grounds in accordance with established hospital policy in order to supplement oral calorie intake immediately after birth, and was phased out gradually as oral intake increased. Feeds were started 24 hours after birth with half-strength half-cream Cow and Gate milk. The infants received $120 \mathrm{ml} / \mathrm{kg}$ per $24 \mathrm{hr}$ intravenous fluid containing $10 \mathrm{~g}$ dextrose and $0.5 \mathrm{~g}$ inulin $/ 100 \mathrm{ml}$ through a constant infusion pump for 72 hours after birth and reduced quantities for at least 24 hours thereafter.

Urine collections were started within one hour of birth

Received 16 August 1973. using a metabolic tray as described by Hepner and Lubchenco (1960) and a sample for analysis was frozen at $-20{ }^{\circ} \mathrm{C}$ without delay at the end of each collecting period. The first specimen passed after birth was assumed to be fetal in origin; if no urine was passed before the baby was placed on the metabolic tray the first specimen collected was placed on one side and analysed separately. Care was taken to prevent contamination with stool, milk, or meconium: two specimens were discarded for this reason. 'Clean catch' specimens of urine were collected from 4 babies and the folate level compared with that found in the preceeding and succeeding pooled 12-hour collections of urine to see whether exogenous bacterial production of folate could be occurring in the collection bottle. There was no evidence to suggest that this was a problem (Table I).

TABLE I

Comparison between folate activity in 'clean catch' and pooled specimens of urine

\begin{tabular}{c|c|c|c}
\hline \multirow{2}{*}{ Case no. } & \multicolumn{3}{|c}{ Folate levels (ng/ml) } \\
\cline { 2 - 3 } & $\begin{array}{c}\text { Prior 12-hour } \\
\text { collection }\end{array}$ & $\begin{array}{c}\text { 'Clean catch' } \\
\text { specimen }\end{array}$ & $\begin{array}{c}\text { Subsequent 12-hour } \\
\text { collection }\end{array}$ \\
\hline 9 & - & 30 & 38 \\
6 & 38 & 51 & 30 \\
11 & 14 & 10 & 14 \\
12 & 6 & 9 & 9 \\
& 15 & 15 & 12 \\
& 18 & 20 & 41 \\
& 41 & 41 & 25 \\
\hline
\end{tabular}

Analysis of residues from the collecting tray and samples of distilled water washed through the collecting system failed to show significant folate activity and the addition of one crystal of thymol to the collecting bottle made no 
detectable difference to the folate content of the urine. Contamination during collection is not, therefore, likely to account for the consistently high folate content of the urine collected while the baby was on the metabolic tray.

'Clean catch' specimens of urine were also collected within 10 minutes of birth from 19 normal infants of 33 to 41 weeks' gestation, and samples of amniotic fluid were obtained from 37 mothers either by amniocentesis shortly before delivery, or at the time the fetal membranes were ruptured during early labour.

Folate activity was measured as described by Herbert (1966) using a commercially available medium (Difco 082). Plasma samples were added aseptically to the sterile medium and urine samples were sterilized with the assay medium which contains sufficient ascorbate to protect labile folate during this procedure. Inulin was measured by the method of Heyrovsky (1956), care being taken to ensure that cooling never caused inulin to precipitate out before analysis. Body surface area was calculated from body weight and crown-heel length using the relation established by Boyd (1935).

\section{Results}

Urine folate activity. The concentration of folate in urine was variable but high throughout the first 5 days of life. Urine folate concentration showed no consistent trend during this time, but the folate concentration of urine formed in utero and passed within 10 minutes of birth was low and much the same as the level found in amniotic fluid (Table II).

Loss during first 5 days. The plasma folate level halved during the first 5 days of life (Table III and Fig. 1), and urinary folate excretion approximately doubled during the same period (Fig. 2). Glomerular filtration (measured as inulin clearance) doubled during the first 5 days but this could not account for the increased loss in the urine
TABLE II

Folate activity in amniotic fluid and in fetal, neonatal, and adult urine $(\mathrm{ng} / \mathrm{ml})$

\begin{tabular}{l|c|c|c}
\hline \multicolumn{1}{c|}{ Subjects } & $\begin{array}{c}\text { No. of } \\
\text { subjects }\end{array}$ & Median & $\begin{array}{c}\text { Interquartile } \\
\text { range* }\end{array}$ \\
\hline $\begin{array}{l}\text { Amniotic fluid at 37-41 } \\
\text { weeks' gestation }\end{array}$ & 37 & $2 \cdot 5$ & $1 \cdot 5-4 \cdot 2$ \\
'Fetal' urine passed within \\
$\begin{array}{l}\text { 10 min of birth } \\
\begin{array}{c}\text { Neonatal urine (mean over } \\
\text { first 5 dy) }\end{array}\end{array}$ & 19 & $2 \cdot 5$ & $1 \cdot 5-5 \cdot 5$ \\
$\begin{array}{l}\text { Adult urine } \\
\text { durine }\end{array}$ & 30 & $\begin{aligned} 17 \cdot 0 \\
4 \cdot 9\end{aligned}$ & $\begin{array}{l}9 \cdot 0-21 \cdot 0 \\
2 \cdot 3-6 \cdot 4\end{array}$ \\
\hline
\end{tabular}

*The range within which $50 \%$ of the observed values fall.

because the kidney handled an almost constant amount of folate per unit time as a result of the fall in plasma folate. There was no apparent difference between folate excretion in preterm and term infants (Table III). The ratio of folate clearance to inulin clearance rose during the first 5 days of life (Fig. 3), and, if it can be assumed that decreased protein binding did not increase the proportion of plasma folate filtered by the glomeruli, the rise in the ratio can be taken as evidence of decreased tubular reabsorption. Calculations suggest that the neonatal kidney may be failing to reabsorb 5 or even $10 \%$ of the folate filtered by the renal glomeruli, but there is nothing in the present data to suggest that tubular reabsorption is influenced either by plasma folate level or by the rate of urine flow.

Loss in late neonatal period. Serial studies of renal folate excretion were undertaken twice a week in one further baby of 32 weeks' gestation (Case 12, Table I) throughout the first month of life: renal excretion exceeded $2.5 \mu \mathrm{g} / \mathrm{kg}$ per 24 hours throughout this period.

TABLE III

Renal loss of folate in the first 5 days of life

\begin{tabular}{|c|c|c|c|c|c|c|c|}
\hline \multirow{2}{*}{ Case no. } & \multirow{2}{*}{ Sex } & \multirow{2}{*}{ Gestation (wk) } & \multirow{2}{*}{ Birthweight (kg) } & \multirow{2}{*}{ Surface area $\left(\mathrm{m}^{2}\right)$} & \multicolumn{2}{|c|}{ Plasma folate $(\mathrm{ng} / \mathrm{ml}$ ) } & \multirow{2}{*}{$\begin{array}{c}\text { Total folate loss } \\
\text { in urine over } \\
5 \mathrm{dy}(\mu \mathrm{g})\end{array}$} \\
\hline & & & & & Birth & $5 \mathrm{dy}$ & \\
\hline $\begin{array}{c}1 \\
2 \\
3 \\
4 \\
5 \\
6 \\
7 \\
8 \\
9 \\
10 \\
\text { Mean }\end{array}$ & $\begin{array}{c}M \\
F \\
M \\
M \\
F \\
F \\
M \\
M \\
M \\
F\end{array}$ & $\begin{array}{l}31 \\
32 \\
33 \\
33 \\
34 \\
35 \\
37 \\
38 \\
39 \\
40\end{array}$ & $\begin{array}{l}1 \cdot 33 \\
1 \cdot 80 \\
2 \cdot 04 \\
2 \cdot 07 \\
1 \cdot 67 \\
2 \cdot 21 \\
2 \cdot 07 \\
2 \cdot 21 \\
2 \cdot 13 \\
2 \cdot 18 \\
1 \cdot 97\end{array}$ & $\begin{array}{l}0 \cdot 117 \\
0 \cdot 147 \\
0 \cdot 160 \\
0 \cdot 162 \\
0 \cdot 139 \\
0 \cdot 171 \\
0 \cdot 162 \\
0 \cdot 171 \\
0 \cdot 165 \\
0 \cdot 168 \\
0 \cdot 156\end{array}$ & $\begin{array}{r}56 \\
35 \\
27 \\
100 \\
24 \\
28 \\
23 \\
21 \\
20 \\
38 \\
43\end{array}$ & $\begin{array}{l}21 \\
15 \\
19 \\
18 \\
16 \\
13 \\
11 \\
14 \\
10 \\
23 \\
16\end{array}$ & $\begin{array}{c}12 \cdot 0 \\
17 \cdot 7 \\
30 \cdot 2 \\
10 \cdot 8 \\
19 \cdot 9 \\
40 \cdot 4^{\star} \\
17 \cdot 1 \\
13 \cdot 2 \\
8 \cdot 7 \\
28 \cdot 7 \\
17 \cdot 6\end{array}$ \\
\hline
\end{tabular}

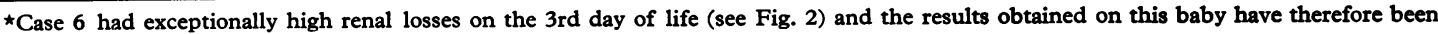
omitted in calculating the overall mean. 


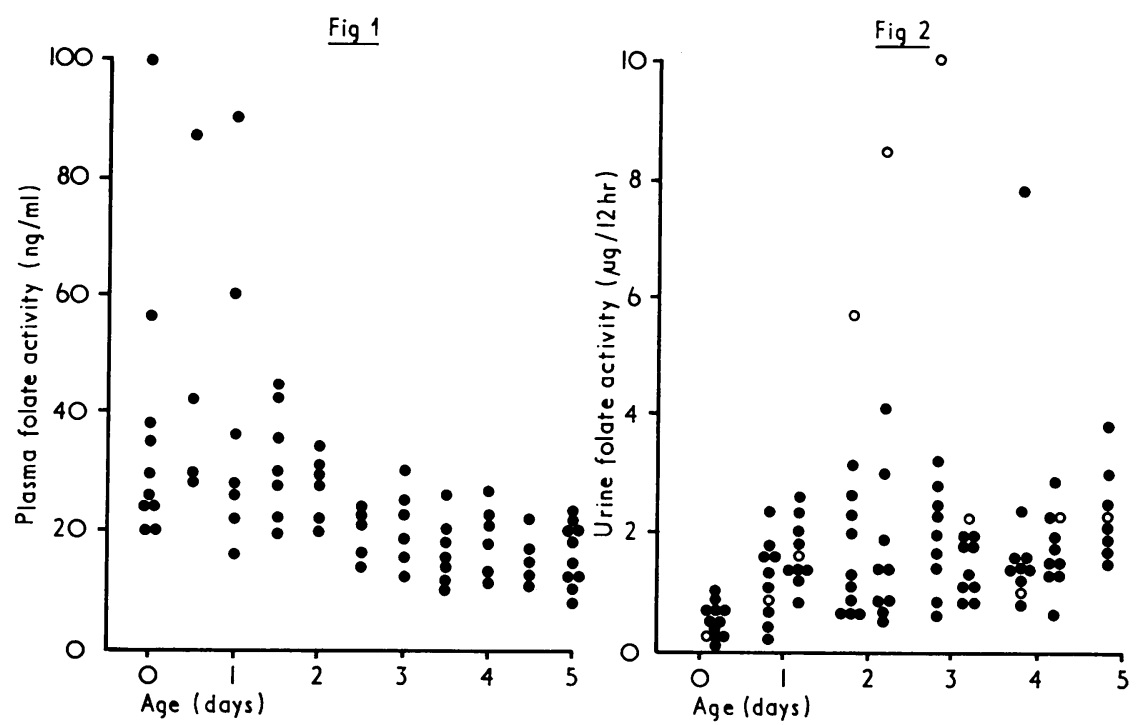

FIG. 1.-Plasma folate activity in the first 5 days of life.

FIG. 2.-Renal loss of folate during the first 5 days of life. (o relates to Case 6 who had an abnormally high folate loss associated with glycosuria on the 3rd day of life.)

\section{Discussion}

Renal loss of folate appears to be considerable in the first week of life. When compared on a surface area basis, daily loss of folate in the urine is nearly 8 times as high as in adult life, and twice as high as in pregnancy (Table IV). The way in which the kidney handles folate is not known for certain, but

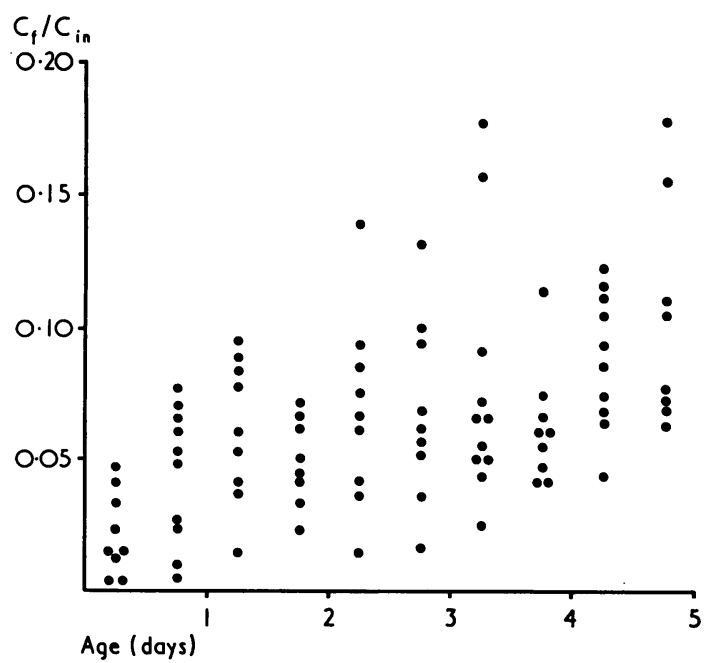

Fig. 3.-Folate clearance $\left(C_{f}\right)$ as a fraction of inulin clearance $\left(C_{i n}\right)$ during the first 5 days of life.
TABLE IV

Renal loss of folate (mean $\pm S D$ )

\begin{tabular}{|c|c|c|}
\hline Subjects & $\mu \mathrm{g} / \mathrm{kg}$ per $24 \mathrm{hr}$ & $\mu \mathrm{g} / \mathrm{m}^{2}$ per $24 \mathrm{hr}$ \\
\hline $\begin{array}{l}10 \text { neonates } \\
1 \text { st dy of life } \\
5 \text { th dy of life } \\
\text { Mean over lst } 5 \mathrm{dy} \\
8 \text { women* } \\
\text { During pregnancy } \\
\text { Post partum } \\
30 \text { normal adultst }\end{array}$ & $\begin{array}{l}0.87 \pm 0.44 \\
1.99 \pm 0.47 \\
1.87 \pm 0.91 \\
0.20 \pm 0.13 \\
0.06 \pm 0.03 \\
0.08 \pm 0.05\end{array}$ & $\begin{array}{l}10 \cdot 9 \pm 5 \cdot 5 \\
24 \cdot 9 \pm 5 \cdot 9 \\
23 \cdot 2 \pm 10 \cdot 3 \\
8 \cdot 1 \pm 5 \cdot 2 \\
2 \cdot 1 \pm 1 \cdot 1 \\
3 \cdot 0 \pm 1 \cdot 9\end{array}$ \\
\hline
\end{tabular}

^From Landon and Hytten (1971).

†M. J. Landon (unpublished data).

free folate seems to be filtered by the glomerulus and largely reabsorbed by the renal tubule (Goresky, Watanabe, and Johns, 1963). The extent to which plasma folate is bound to protein may not be the same at birth as it is in adult life, but changes in protein-binding cannot explain the difference in renal loss. If we assume that one-third of the folate in plasma is bound to protein at birth as well as in adult life (Retief and Huskisson, 1970; Markkanen and Peltola, 1970), then the neonatal kidney reabsorbs about $90 \%$ of the filtered folate, whereas the adult kidney reabsorbs $99.5 \%$. The rise in the concentration cf folate in the urine immediately after delivery (Table II) and the progressive fall in tubular reabsorption during the first 5 days of life 
(Fig. 3) could be due to increased saturation of the absorptive mechanism and there is some evidence that significant storage of folate occurs within the tubular cells (Goresky et al., 1963). There was, however, no evidence that percentage tubular reabsorption was affected by the size of the filtered load in the present study.

Shojania and Hornady (1970) found that 7- to 11-day-old infants excreted less of a $40 \mu \mathrm{g} / \mathrm{kg}$ body weight dose of intramuscular folic acid in their urine than adults; however, the fall in plasma folate after such an injection was much more rapid in the neonatal period, and this probably explains the low renal excretion.

Other nutrients are already known to be excreted in excess during the first few weeks of life. Jusko et al. (1970) found renal excretion of riboflavin to be comparatively high in the neonatal period and suggested that this was due to poor tubular reabsorption. A relative aminoaciduria has been reported in early infancy (Woolf and Norman, 1957; Armstrong, Yates, and Connelly, 1964) and Brodehl and Gellissen (1968) have suggested that this may be partly because of imbalance between glomerular and tubular development. The amino acid content of the urine rises immediately after birth (Cockburn $e t$ al., 1973) like the concentration of folate (Table II), and this may be an indication that glomerular filtration in man rises rapidly at birth, just as it does in the guinea pig (Boylan, Colbourn, and McCance, 1958).

In the present study, renal losses were more than enough to account for the observed fall in plasma folate, even in the infant who had a cord plasma folate of $100 \mathrm{ng} / \mathrm{ml}$ because of maternal folate medication. This implies that folate was being drawn into the general circulation from the tissues. We do not know how long this drain on body stores continues: in the one preterm infant that we have studied so far, renal losses remained high throughout the first month of life.

The significance of this urinary loss is conjectural because it is difficult to assess the normal requirement for folate during infancy. A minimum daily intake of $5 \mu \mathrm{g} / \mathrm{kg}$ has been recommended (Ghitis, 1966; Sullivan, Luhby, and Streiff, 1966), while a recent report of a joint FAO/WHO expert group (1970) suggested a daily intake of $40 \mu \mathrm{g}$. The folate content of artificial milk preparations may be much lower because of losses during preparation (Ghitis, 1966), and Roberts et al. (1969) suggested that daily intake from milk preparations would range from 2 to $10 \mu \mathrm{g}$ folate for a $3 \mathrm{~kg}$ baby-roughly equivalent to the amount excreted in the urine by many of the infants in the present study. If these estimates are correct it would imply that until the infant achieves a more adequate intake, it is dependent on folate supplies received in utero to meet its daily requirements. The low folate levels seen in infants with diarrhoea, malnutrition, and infection (Kende, Ramot, and Grossowicz, 1963; Matoth et al., 1964; Friedman et al., 1964; Gray and Butler, 1965) and the rapid uptake of intravenously administered folic acid suggest that folate stores are often marginal at this time.

We thank the staff of the Special Care Nursery at the Princess Mary Maternity Hospital for helping to collect the urine specimens. E.N.H. held an M.R.C. Clinical Research Fellowship.

\section{REFERERCES}

Armstrong, M. D., Yates, K. N., and Connelly, J. P. (1964). Amino acid excretion of newborn infants during the first twenty-four hours of life. Pediatrics, 33, 975.

Boyd, E. (1935). The Growth of the Surface Area of the Human Body, p. 100. University of Minnesota Press, Minneapolis.

Boylan, J. W., Colbourn, E. P., and McCance, R. A. (1958). Renal function in the foetal and new-born guinea-pig. fournal of Physiology, 141, 323.

Brodehl, J., and Gellissen, K. (1968). Endogenous renal transport of free amino acids in infancy and childhood. Pediatrics, 42, 395.

Cockburn, F., Giles, M., Robins, S. P., and Forfar, J. O. (1973). Free amino acid composition of human amniotic fluid at term. fournal of Obstetrics and Gynaecology of the British Commonwealth, 80, 10.

Food and Agriculture Organization/World Health Organization (1970). Requirements of ascorbic acid, vitamin $D$, vitamin $B_{12}$, folate, and iron. WHO Technical Report Series, No. 452. World Health Organization, Geneva.

Friedman, R., McKensie, D., Turner, T., and Wittman, W. (1964). Folic acid deficiency in infantile gastroenteritis. South African fournal of Laboratory and Clinical Medicine, 10, 69.

Ghitis, J. (1966). The labile folate of milk. American fournal of Clinical Nutrition, 18, 452.

Goresky, C. A., Watanabe, H., and Johns, D. G. (1963). The renal excretion of folic acid. Fournal of Clinical Investigation, 42, 1841.

Gray, O. P., and Butler, E. B. (1965). Megaloblastic anaemia in premature infants. Archives of Disease in Childhood, 40, 53.

Hepner, R., and Lubchenco, L. O. (1960). A method for continuous urine and stool collection in young infants. Pediatrics, 26, 828.

Herbert, V. (1966). Aseptic addition method for Lactobacillus casei assay of folate activity in human serum. Fournal of Clinical Pathology, 19, 12.

Heyrovsky, A. (1956). A new method for the determination of inulin in plasma and urine. Clinica Chimica Acta, 1, 470.

Jusko, W. J., Khanna, N., Levy, G., Stern, L., and Yaffe, S. J. (1970). Riboflavin absorption and excretion in the neonate. Pediatrics, 45, 945.

Kende, G., Ramot, B., and Grossowicz, N. (1963). Blood folic acid and vitamin $B_{12}$ activities in healthy infants and in infants with nutritional anaemias. British fournal of Haematology, 9, 328.

Landon, M. J., and Hytten, F. E. (1971). The excretion of folate in pregnancy. Fournal of Obstetrics and Gynaecology of the British Commonwealth, 78, 769.

Landon, M. J., and Oxley, A. (1971). Relation between maternal and infant blood folate activities. Archives of Disease in Childhood, 46, 810.

Markkanen, T., and Peltola, O. (1970). Binding of folic acid activity by body fluids. Acta Haematologica, 43, 272.

Matoth, Y., Zamir, R., Bar-Shani, S., and Grossowicz, N. (1964). Studies on folic acid in infancy. II. Folic and folinic acid blood levels in infants with diarrhea, malnutrition, and infection. Pediatrics, 33, 694.

Retief, F. P., and Huskisson, Y. J. (1970). Folate binders in body fluids. Fournal of Clinical Pathology, 23, 703. 
Roberts, P. M., Arrowsmith, D. E., Rau, S. M., and Monk-Jones, M. E. (1969). Folate state of premature infants. Archives of Disease in Childhood, 44, 637.

Shojania, A. M., and Hornady, G. (1970). Folate metabolism in newborns and during early infancy. Pediatric Research, 4, 422.

Strelling, M. K., Blackledge, G. D., Goodall, H. B., and Walker, C. H. M. (1966). Megaloblastic anaemia and whole-blood folate levels in premature infants. Lancet, $1,898$.

Sullivan, L. W., Luhby, A. L., and Streiff, R. R. (1966). Studies of the daily requirement for folic acid in infants and the etiology of folate deficiency in goat's milk megaloblastic anemia. (Abst.) American Fournal of Clinical Nutrition, 18, 311.
Vanier, T. M., and Tyas, J. F. (1966). Folic acid status in normal infants during the first year of life. Archives of Disease in Childhood, 41, 658.

Woolf, L. I., and Norman, A. P. (1957). The urinary excretion of amino acids and sugars in early infancy. Fournal of Pediatrics, $50,271$.

Correspondence to Dr. M. J. Landon, M.R.C. Reproduction and Growth Unit, Princess Mary Maternity Hospital, Great North Road, Newcastle upon Tyne NE2 3BD. 